\title{
Article \\ Arsenic Contamination in Groundwater and Potential Health Risk in Western Lampang Basin, Northern Thailand
}

\author{
Nipada Santha ${ }^{1}$, Saowani Sangkajan ${ }^{2}$ and Schradh Saenton ${ }^{1,3,4, * \mathbb{C}}$ \\ 1 Department of Geological Sciences, Faculty of Science, Chiang Mai University, Chiang Mai 50200, Thailand; \\ nipada.santha@cmu.ac.th \\ 2 Bureau of Groundwater Resources Region 1, Department of Groundwater Resources, \\ Ministry of Environment and Natural Resources, Lampang 52130, Thailand; saowani.s@dgr.mail.go.th \\ 3 Environmental Science Research Center (ESRC), Faculty of Science, Chiang Mai University, \\ Chiang Mai 50200, Thailand \\ 4 Advanced Research Center for Computational Simulation (ARCCoS), Chiang Mai University, \\ Chiang Mai 50200, Thailand \\ * Correspondence: schradh.saenton@cmu.ac.th; Tel.: +66-5394-3490 (ext. 1073)
}

Citation: Santha, N.; Sangkajan, S.; Saenton, S. Arsenic Contamination in Groundwater and Potential Health Risk in Western Lampang Basin, Northern Thailand. Water 2022, 14, 465. https://doi.org/10.3390/ w14030465

Academic Editors: Jean O'Dwyer and Paul Hynds

Received: 21 December 2021

Accepted: 3 February 2022

Published: 4 February 2022

Publisher's Note: MDPI stays neutral with regard to jurisdictional claims in published maps and institutional affiliations.

Copyright: (C) 2022 by the authors. Licensee MDPI, Basel, Switzerland. This article is an open access article distributed under the terms and conditions of the Creative Commons Attribution (CC BY) license (https:// creativecommons.org/licenses/by/ $4.0 /)$.

\begin{abstract}
This research aimed to investigate the spatial distribution of arsenic concentrations in shallow and deep groundwaters which were used as sources for drinking and domestic and agricultural uses. A geochemical modeling software PHREEQC was used to simulate equilibrium geochemical reactions of complex water-rock interactions to identify arsenic speciation and mineral saturation indices based on groundwater quality and hydrogeochemical conditions. In addition, the potential health risk from arsenic-contaminated groundwater consumption was assessed based on the method developed by the U.S. Environmental Protection Agency. The study area is located at the western part of the Lampang Basin, an intermontane aquifer, Northern Thailand. The area is flat and situated in a floodplain in the Cenozoic basin. Most shallow groundwater ( $\leq 10 \mathrm{~m}$ depth) samples from dug wells were of $\mathrm{Ca}-\mathrm{Na}-\mathrm{HCO}_{3}$ and $\mathrm{Ca}-\mathrm{HCO}_{3}$ types, whereas deep groundwater from Quaternary terrace deposits (30-150 m depth) samples were of $\mathrm{Na}-\mathrm{HCO}_{3}$ and $\mathrm{Ca}-\mathrm{Na}-\mathrm{HCO}_{3}$ types. High arsenic concentrations were found in the central part of the study area (Shallow groundwater: $<2.8-35 \mathrm{mg} / \mathrm{L}$ with a mean of $10.7 \mathrm{mg} / \mathrm{L}$; Deep groundwater: $<2.8-480 \mathrm{mg} / \mathrm{L}$ with a mean of $51.0 \mathrm{mg} / \mathrm{L})$. According to geochemical modeling study, deep groundwater contained toxic As(III), as the dominant species more than shallow groundwater. Arsenic in groundwater of the Lampang Basin may have been derived from leaching of rocks and could have been the primary source of the subsurface arsenic in the study area. Secondary source of arsenic, which is more significant, could be derived from the leaching of sorbed arsenic in aquifer from co-precipitated Fe-oxyhydroxides in sediments. Quantitative risk assessment showed that the average carcinogenic risk values were as high as $2.78 \times 10^{-3}$ and $7.65 \times 10^{-3}$ for adult and child, respectively, which were higher than the acceptable level $\left(1 \times 10^{-4}\right)$. The adverse health impact should be notified or warned with the use of this arsenic-contaminated groundwater without pre-treatment.
\end{abstract}

Keywords: arsenic; groundwater; health risk assessment; PHREEQC; Lampang; Thailand

\section{Introduction}

Groundwater is the main freshwater resource for consumption and utilization in many parts of the world because of its large amount reserves and less microbial contamination [1,2], but it can be naturally contaminated by heavy metals. Arsenic (As) is one of the most toxic elements in groundwater which has a potential risk relating to multiple health problems, including cancers of the bladder, lungs, skin, kidney, nasal passages, liver, and prostate [3,4]. In recognition of the health risk associated with arsenic, maximum contaminant level (MCL) of arsenic for Thailand's groundwater standard is set at 50 microgram per liter $(\mu \mathrm{g} / \mathrm{L})$ [5], while MCL of arsenic for drinking water is $10 \mu \mathrm{g} / \mathrm{L} \mathrm{[6].} \mathrm{Arsenic} \mathrm{can} \mathrm{be} \mathrm{found} \mathrm{in} \mathrm{several}$ 
types of aquifers, including unconsolidated sediments and consolidated igneous, metamorphic, and sedimentary rocks [7-11]. Arsenic can release into the aqueous phase from the dissolution of minerals/rocks or leaching of sorbed arsenic species. The dissolved arsenic primarily exists in oxy-anions, including arsenite $\mathrm{As}(\mathrm{III})$, arsenate $\mathrm{As}(\mathrm{V})$, and arsenide As(-3) [12], depending on $\mathrm{pH}$ and redox potential. However, only $\mathrm{As}(\mathrm{III})$ or $\mathrm{As}(\mathrm{V})$ are dominant species in groundwater $[13,14]$. Based on thermodynamics, $\mathrm{As}(\mathrm{V})$ is predominant under oxidizing conditions, and As(III) is mainly present in reducing environment and both can coexist in groundwater $[15,16]$. The mobility of these species is controlled by $\mathrm{pH}$, redox potential, and the presence of adsorbents, such as iron and manganese (hydr)oxides and clay minerals $[17,18]$. The complexity of spatial distribution, fate, and transport of arsenic in groundwater are mainly controlled by geochemical conditions and processes depending on geologic setting characters. Despite the presence of natural adsorbents in aquifers, the transport of arsenic in groundwater under natural conditions at some sites could still take place at high rates $[19,20]$. Therefore, the unique and individual features of the source rocks, aquifer materials, and hydrogeochemical conditions are the key characteristics of the study of arsenic contamination.

The presence of arsenic in groundwater may pose a potential health risk, especially in countries that utilize arsenic-contaminated groundwater as a main source of drinking water. Several parts of the world were revealed to have been impacted by the presence of excessive amounts of arsenic in their sources of drinking water, including South America (i.e., Argentina, Chile, Mexico), Asia (i.e., China, India, Bangladesh), Southeast Asia (i.e., Vietnam, Indonesia, Myanmar, Thailand) [12,21-23], and Europe, such as in central Italy [24]. Comparing the spatial database of arsenic contamination in all regions, Southeast Asia, including Myanmar and Thailand, is the most limited [12,21].

In Northern Thailand, the western part of Lampang Basin is densely populated and the most common occupation is agriculture, both of which lead to an increased demand for groundwater supply [25]; however, it was reported that there was arsenic contamination in deep groundwater in the Lampang Basin [26]. As a consequence, the Department of Groundwater Resources (DGR) [25] conducted a reconnaissance survey on the distribution of arsenic in shallow groundwater and it was suggested that arsenic could have entered the groundwater system via a hazardous waste landfill or pesticide-polluted overflow which directly ran through wells during a period of flooding. The Bureau of Groundwater Resources Region 1, Department of Groundwater Resources, was subsequently requested by the Lampang Provincial Health Office to investigate the arsenic source and level in groundwater. The preliminary study showed that there were 12 samples from groundwater wells with arsenic concentration ranging from 4.6 to $175.4 \mu \mathrm{g} / \mathrm{L}$ and five samples from dug wells (shallow groundwater) at depth less than $10 \mathrm{~m}$ with arsenic level ranging from 1 to $10 \mu \mathrm{g} / \mathrm{L}$ in dry season. However, the arsenic content in shallow dug wells in wet seasons were very low (and non-detected in some wells) compared to dry season suggesting dilution effect from precipitation. The results from this study indicate that arsenic concentration in deep groundwater wells was higher than the regulated standard of $50 \mu \mathrm{g} / \mathrm{L}$ [5] and some groundwater wells contained arsenic concentrations greater than the WHO's standard for drinking water, $10 \mu \mathrm{g} / \mathrm{L}$ [6]. Groundwater containing arsenic could result in adversely affect health if humans directly consume the groundwater by drinking or using it in the preparation of food; high risk levels of arsenic can cause short-term or acute symptoms, as well as long-term or chronic health effects. Even though there is a potential health risk associated with arsenic in groundwater of the Lampang Basin; its source, fate, transport, and distribution require further study.

The paper aimed at investigating the source and distribution of arsenic in deep (30-150 $\mathrm{m}$ below ground surface or bgs (below ground surface)) and shallow ( $\leq 10 \mathrm{~m} \mathrm{bgs}$ ) groundwaters in the western part of Lampang Basin (see Figure 1), as well as assessing potential health risk due to the consumption of arsenic-contaminated groundwaters. Specific objectives included: (1) investigating arsenic contamination and distribution through analyses of sampled groundwater; (2) delineating the source of arsenic in groundwater; 
and (3) assessing the associated potential health risk. By realizing the extent and severity of arsenic problem, a better plan on groundwater management and usage can be suggested. Groundwater samplings and geochemical modeling studies were conducted to delineate the concentration, as well as the source of arsenic, in deep aquifers in the western part of the Lampang Basin.

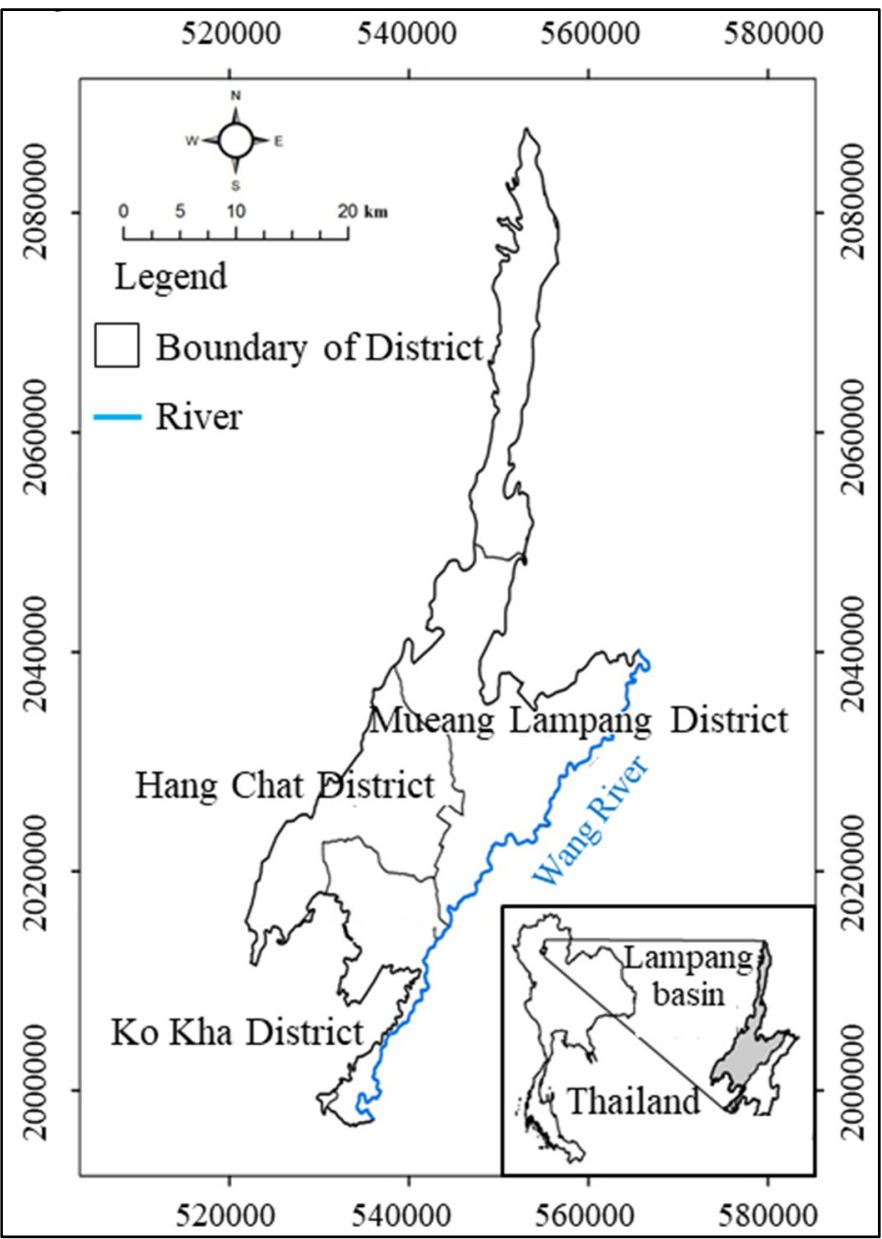

Figure 1. Western part of the Lampang Basin, Lampang province, Northern Thailand with Wang river flowing from north to south.

\section{Materials and Methods}

The methods employed in this study included groundwater, rock and sediment samplings, chemical analyses in groundwater, rocks and sediments, arsenic leachability test from sediment samples, and chemical speciation modeling using a U.S. Geological Survey geochemical modeling tool PHREEQC (pH-REdox-EQuilibrium written in C programming version 3) [27]. Lastly, the potential health risk was assessed based on the U.S. Environmental Protection Agency method [28].

\subsection{Study Area}

The Lampang Basin is located in Northern Thailand between UTM-E: 522,000 to 567,000 and UTM-N: 1,996,500 to 2,088,000. The area covers approximately $900 \mathrm{~km}^{2}$. The $380 \mathrm{~km}$ long major river, Wang river, flows from north to south, as shown in Figure 1. The rainy season generally lasts from May to October, with the highest record of rainfall in September (146-210 mm). November to April is a dry season, with the lowest level rainfall occurring in January (5.6-7.6 mm) (Thailand's Meteorological Department, Ministry of Information and Communication Technology). 
The geologic units of western part of Lampang Basin shown in Figure 2 can be described as follows. The central part of the basin is covered by Quaternary unconsolidated sediments with Tertiary semi-consolidated sediments basement. The sediments consist of fluvial deposits (Qa: gravel, sand, silt, and clay) along floodplain of Wang river, floodplain deposits (Qff: overbank clay, gray to light gray, partly intercalated with gravelly sand lens) covering southwestern portions of the area, colluvial and residual deposits (Qc: gravel, sand, silt, laterite, and rock fragments), terrace deposits (Qt: gravel, sand, silt, clay, and laterite) distributing along the Wang River, and semi-consolidated deposits (Tmm), covering central portions of the area [29]. The unconsolidated and semi-consolidated sediments are surrounded by Silurian-Devonian metamorphic rocks (SD; phyllite, carbonaceous phyllite, and quartzitic phyllite), Permo-Triassic volcanic rocks (PTrv; rhyolite, andesite, ash-flow tuff, volcanic breccia, rhyolitic tuff and andesitic tuff, and Triassic deposits), Triassic deposits (Trhh; mudstone, gray to dark gray, intercalated sandstone, thin- to thickbedded, common with bivalve Halobia sp., Daonella sp.), and Triassic granites (Trgr; biotite granite, tourmaline granite, granodiorite, biotite-muscovite granite, muscovite-tourmaline granite, and biotite-tourmaline granite) [29].

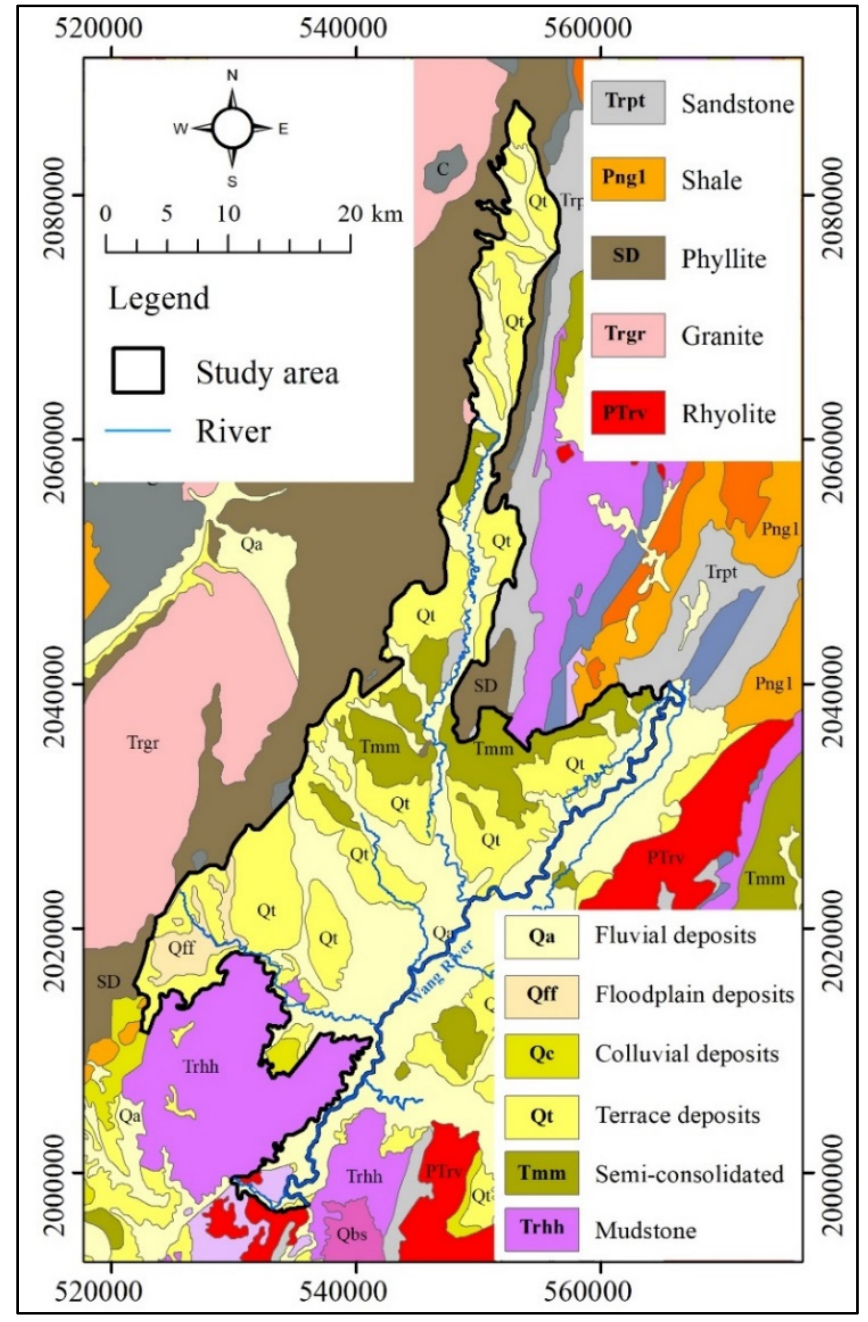

Figure 2. Geologic map of Lampang Basin (modified from [29]).

The main hydrogeologic units $(\mathrm{Qt})$ consist of two major aquifers: shallow and deep units. The shallow aquifer unit consists of gravel, sand, silt, clay being deposited along a narrow terrace of Wang flood plain with the maximum depth of aquifer ranging from 15 to $40 \mathrm{~m}$ bgs. The deeper aquifer unit consisting of gravel, sand, silt and clay has the 
maximum depth ranging from 90 to $150 \mathrm{~m}$ bgs. Well yield in the Qt aquifers range from 2 to $10 \mathrm{~m}^{3} / \mathrm{h}[30]$.

\subsection{Groundwater, Rock, and Sediment Samplings}

Groundwater samples were collected from shallow dug wells ( $\leq 10 \mathrm{~m}$ depth) and deep groundwater wells of Qt aquifers (30-150 m depth). Shallow groundwater was sampled in March-April which is the dry season, in order to avoid the influence of precipitation. No groundwater sample from dug well was collected during rainy season because the preliminary study by the Department of Groundwater Resource found that very low arsenic content was detected during high infiltration of precipitation [25]. In deeper aquifer, which is mainly unconsolidated sediments of Qt unit, groundwater was sampled twice over a year during August-September (wet season) and March-April (dry season). Both shallow dug wells and deep groundwater wells were selected to be evenly distributed in the study area. Shallow groundwater samples were collected from 20 dug wells based on field survey and deep groundwater samples were chosen from 50 public wells from the registered wells listed in the database of Thailand's Department of Groundwater Resource (see Figure 3).
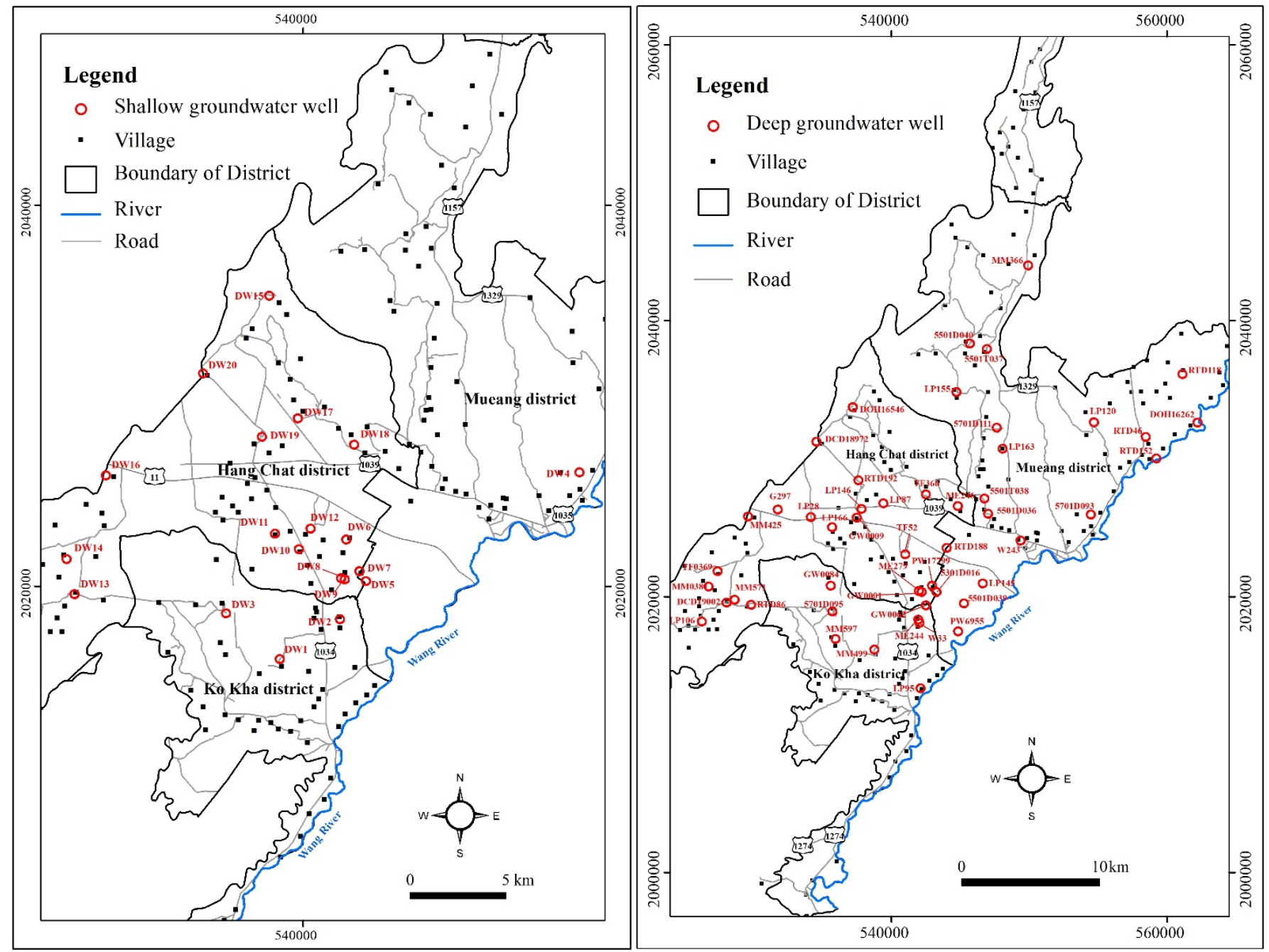

Figure 3. Locations of shallow (left) and deep groundwater wells (right).

Prior to groundwater sampling, water levels of wells were measured using electric measuring tapes. The groundwater sampling was conducted after being pumped for 15-20 min (approximately 2 pore volumes) in order to ensure representative samples. All samples were collected using two $250 \mathrm{~mL}$ rinsed polyethylene (PE) bottles and stored at $4{ }^{\circ} \mathrm{C}$. The first bottle was fixed, before storage, with $1.0 \mathrm{M}$ nitric acid $\left(\mathrm{HNO}_{3}\right)$ for analysis 
of major cations ( $\mathrm{Ca}, \mathrm{Mg}$, $\mathrm{Na}$, and $\mathrm{K}$ ), heavy metals (Fe and $\mathrm{Mn}$ ), and arsenic. The second bottle was collected and capped immediately (non-acidified) for analysis of TDS and anions $\left(\mathrm{CO}_{3}, \mathrm{SO}_{4}, \mathrm{Cl}, \mathrm{F}\right.$, and $\left.\mathrm{NO}_{3}\right)$. Groundwater sample was also analyzed onsite for their physical parameters including redox potential $(\mathrm{Eh})$, temperature $(\mathrm{T})$, electrical conductivity $(\mathrm{EC})$ and $\mathrm{pH}$ using Aqua TROLL 400 Multiparameter Probe.

Unconsolidated sediments (Qa and Qt) samples were collected during groundwater well drillings in the western part of the Lampang Basin. The samples were collected at 2-3 m intervals for shallow depth and 10-12 m intervals for deep aquifer. The locations of sediment sampling in shallow and deep wells are shown in Figure 4.

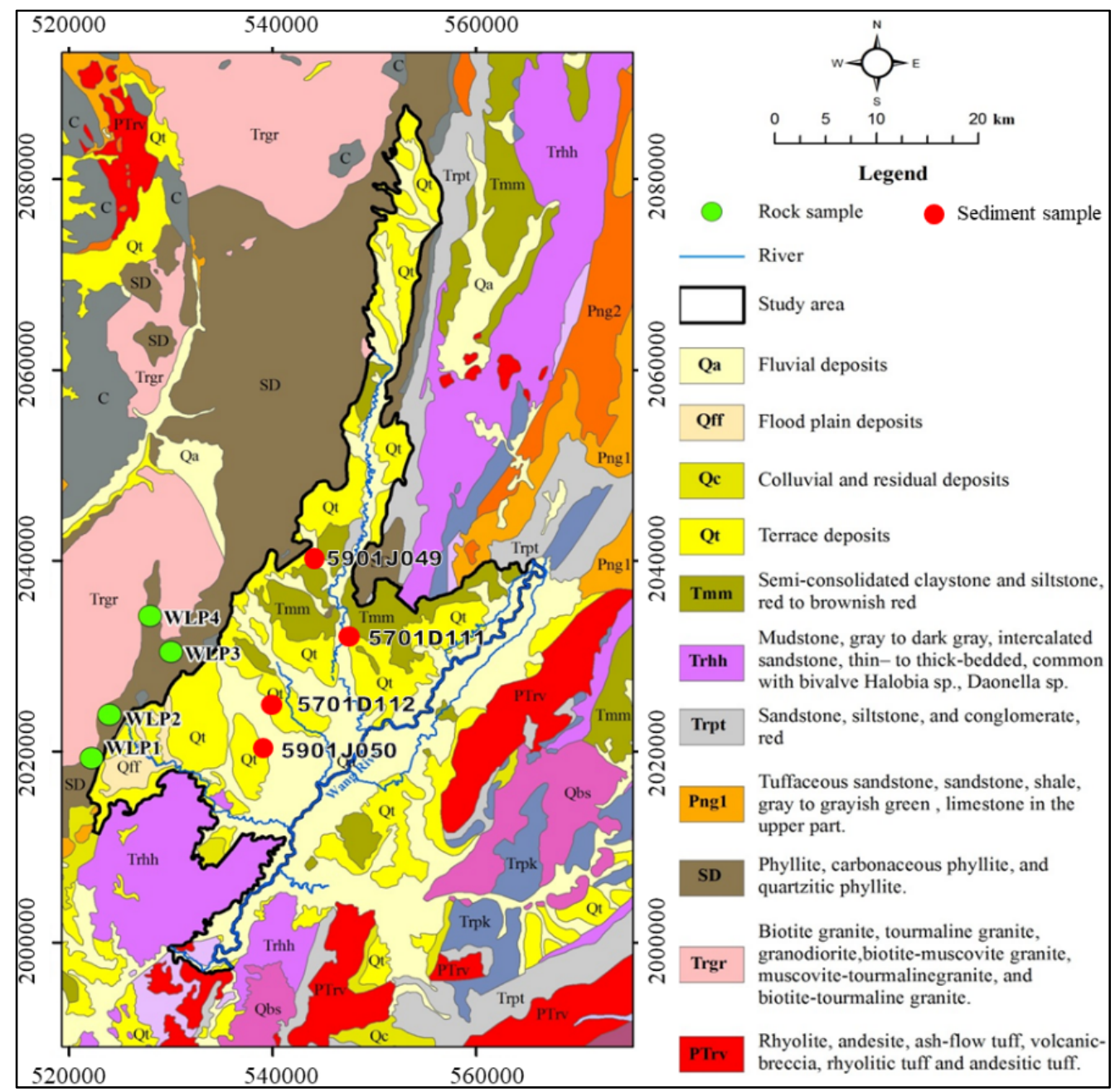

Figure 4. Sediment and rock sampling locations in the western part of the Lampang Basin.

Four rock types including granite (Trgr), sandstone, phyllite and slate (SD) were collected from the outcrops in the study area, as shown in Figure 4. Three replicates were collected for each type of rocks.

\subsection{Chemical Analyses}

Groundwater samples were analyzed for major ions, total hardness as $\mathrm{CaCO}_{3}$, total dissolved solid (TDS), iron, manganese, and arsenic. The acidified groundwater sample was analyzed for major ions and some heavy metals ( $\mathrm{Ca}, \mathrm{Mg}, \mathrm{Na}, \mathrm{K}, \mathrm{Fe}, \mathrm{Mn}$ ) by Atomic Absorption Spectrophotometer (AAS) and for arsenic by Inductive Coupled Plasma Mass Spectrometer (ICP-MS). The non-acidified water sample was analyzed for sulfate, chloride, fluoride, nitrate, and bicarbonate ions using titration method. All experiment was con- 
ducted by the Division of Groundwater Analysis, Department of Groundwater Resources, Bangkok, Thailand.

Rock samples were crushed to a size of $<0.5 \mathrm{~mm}$ using a chisel, hammer, and agate mortar. Arsenic content in each rock sample was determined by acid digestion with nitric $\left(\mathrm{HNO}_{3}\right)$ and hydrochloric $(\mathrm{HCl})$ acids using a microwave digestion system. Sequential extraction was performed on each sample using the method developed by Wenzel et al. [31]. All extracted or digested solutions were passed through a $0.45 \mu \mathrm{m}$ filter, and the arsenic content was measured using ICP-MS (Model 7500ce equipped with an Octapole Reaction System (ORS, Agilent Technologies Inc., Palo Alto, CA, USA.) which was conducted at the Central Laboratory (Chiang Mai, Thailand) Co., Ltd., Chiang Mai Branch.

\subsection{Leachability of Arsenic from Sediments}

Arsenic leachability in the sediment samples was conducted by using $10.0 \mathrm{~g}$ of crushed sediment samples from aquifer materials (Qa and Qt) which was mixed with $200 \mathrm{~mL}$ of deionized water. The solution was adjusted to $\mathrm{pH}>12$ by adding $2.0 \mathrm{M}$ of $\mathrm{NaOH}$ to ensure total leaching or desorbing of arsenic [32,33]. The mixture was soaked in a rotary agitation for at least $48 \mathrm{~h}$, which was earlier experimented and found to be the minimum soaking duration attain equilibrium conditions. The mixture was then filtered with $0.45 \mu \mathrm{m}$ cellulose acetate filter and the solution was adjusted to low $\mathrm{pH}$ using $1.0 \mathrm{M}$ of nitric acid. The solution was then centrifuged and supernatant was filtered and, subsequently, analyzed for arsenic content by ICP-MS at the Department of Groundwater Resources, Bangkok. Analysis of each sample was repeated in three replicates.

\subsection{Geochemical Modeling}

A geochemical modeling tool, PHREEQC [27] with a MINTEQ database [34], was used to simulate the water-rock interaction through a system of equilibrium geochemical reactions of aqueous phase. The model input parameters included $\mathrm{pH}, \mathrm{T}, \mathrm{Eh}$, and total concentrations of all analyzed chemical constituents. The PHREEQC program iteratively solved a system of non-linear chemical equilibrium equations to determine speciation and saturation indices of possible minerals. Specifically, the model output consisted of charge balance calculation, aqueous species concentration in molality $(\mathrm{mol} / \mathrm{kg})$, and saturation indices of possible minerals. The speciation output of arsenic was reported in molality of arsenic species, including $\mathrm{As}(\mathrm{III})$ (e.g., $\mathrm{H}_{3} \mathrm{AsO}_{3}, \mathrm{H}_{2} \mathrm{AsO}_{3}{ }^{-}, \mathrm{HAsO}_{3}{ }^{2-}, \mathrm{H}_{4} \mathrm{AsO}_{3}{ }^{+}, \mathrm{AsO}_{3}{ }^{3-}$ ) and $\mathrm{As}(\mathrm{V})$ (e.g., $\mathrm{HAsO}_{4}{ }^{2-}, \mathrm{H}_{2} \mathrm{AsO}_{4}{ }^{-}, \mathrm{AsO}_{4}{ }^{3-}, \mathrm{H}_{3} \mathrm{AsO}_{4}$ ). Saturation indices of minerals, especially the $\mathrm{Fe}(\mathrm{III})$ compounds, were also reported to infer the presence of solid phases of Fe(III)-oxyhydroxides. The presence of Fe(III)-oxyhydroxides compounds, which are known to effectively adsorb arsenic species at $\mathrm{pH}$ less than 9.5 [35], can be used to indirectly assess the amount of non-sorbed arsenic species.

\subsection{Health Risk Assessment}

A carcinogenic health risk assessment from intaking arsenic-contaminated groundwater was analyzed based on the method outlined by the U.S. EPA [28]. The carcinogenic risk $(\mathrm{R})$ is given in Equation (1) as:

$$
\mathrm{R}=\mathrm{PF} \times \mathrm{ADD}
$$

where PF is the potency (or slope) factor for arsenic. In this work, the value of PF of $1.5(\mathrm{mg} / \mathrm{kg}-\mathrm{d})^{-1}$ was used to calculate carcinogenic risk $[36,37]$. ADD is the average daily dose, which can be calculated by Equation (2):

$$
\mathrm{ADD}=\frac{\mathrm{C} \times \mathrm{I} \times \mathrm{F} \times \mathrm{D}}{\mathrm{A} \times \mathrm{W}}
$$

The parameter $\mathrm{C}$ is arsenic concentration in drinking groundwater $(\mathrm{mg} / \mathrm{L}), \mathrm{I}$ is the intake rate $(2.0 \mathrm{~L} /$ day for adult and $1.0 \mathrm{~L} / \mathrm{d}$ for child), $\mathrm{F}$ is exposure frequency $(365 \mathrm{~d} /$ year), $\mathrm{D}$ is exposure duration (70 $\mathrm{y}$ for adult and $10 \mathrm{y}$ for child), A is average life-span $(70 \times 365 \mathrm{~d}$ 
for adult and $10 \times 365 \mathrm{~d}$ for child), and $\mathrm{W}$ is average body weight (55 $\mathrm{kg}$ for adult and $10 \mathrm{~kg}$ for child) [36,37]. The maximum acceptable carcinogenic risk is $1 \times 10^{-4}$ [28]. The hazard quotient (HQ) was also evaluated using Equation (3):

$$
\mathrm{HQ}=\mathrm{ADD} \div \mathrm{RfD}
$$

where $\mathrm{RfD}=3 \times 10^{-4} \mathrm{mg} / \mathrm{kg}-\mathrm{d}$ [28] is the reference dose used in this study. The value of HQ greater than 1 is attributed to human health risk.

\section{Results and Discussion}

\subsection{Groundwater Flow Direction}

The groundwater flow map was constructed using potentiometric heads measured from deep groundwater wells, as shown in Figure 5. The groundwater flow was topographically driven; the regional flow direction was from higher terrain, in the west and north, toward lower lands, in the eastern and southeastern regions.

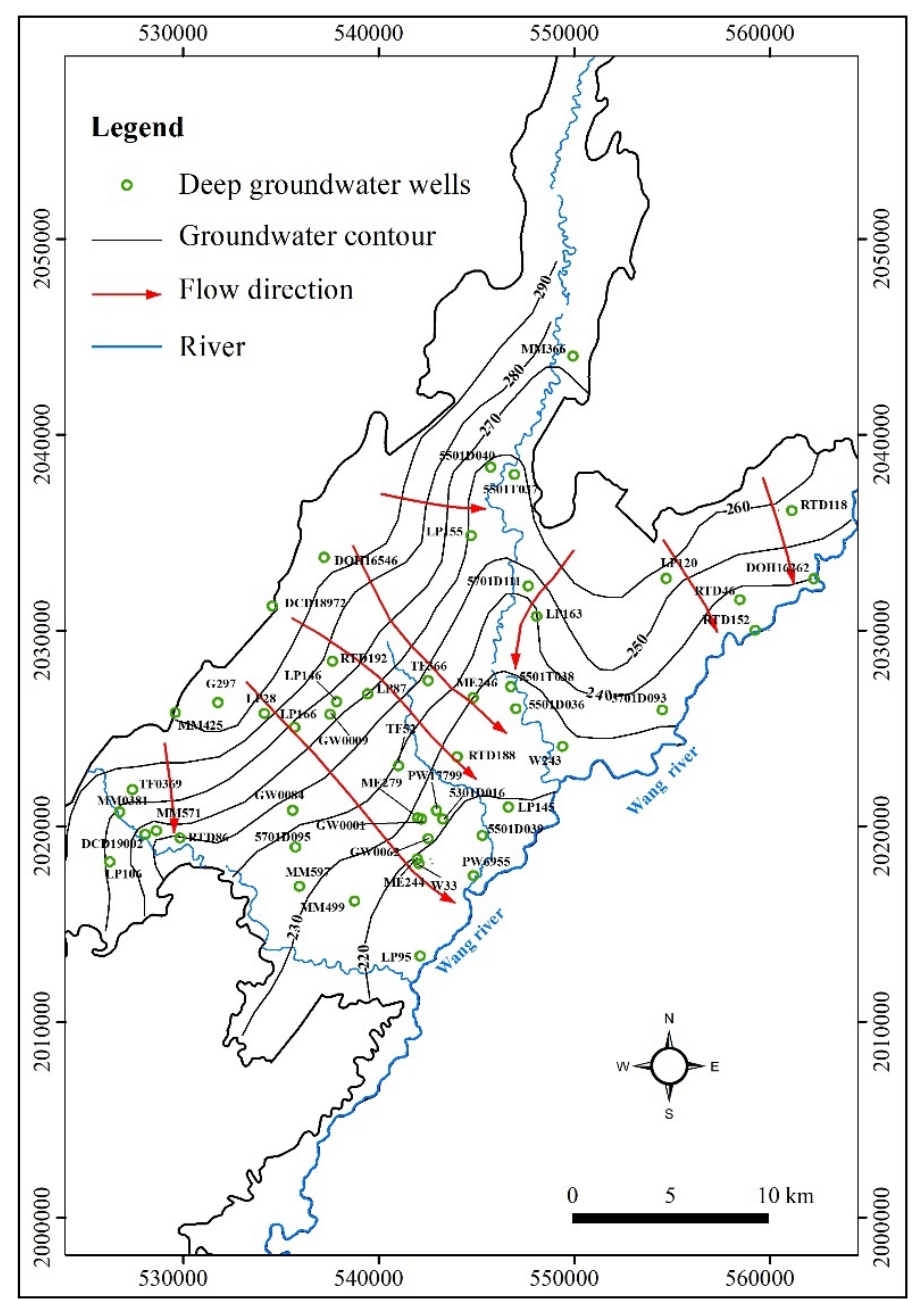

Figure 5. A groundwater contour map of western Wang basin showing groundwater flow directions in deep aquifer toward Wang river, a major river of the basin flowing from north to south.

\subsection{General Groundwater Quality}

Physicochemical properties, as well as groundwater chemical analysis results, are illustrated in Table 1. The redox potential (Eh) in deep groundwater ranges between -131 and $+171 \mathrm{mV}$ in the dry season and between -32 and $168 \mathrm{mV}$ in the wet season, with average values of -13.3 and $-3.6 \mathrm{mV}$, respectively, indicating a reducing condition for the deep aquifer. The shallow aquifer, on the other hand, was in a more oxidizing 
condition (average $\mathrm{Eh}=+73 \mathrm{mV}$ ). One would, therefore, expect that a fraction of toxic As(III) in deep groundwater should be higher than shallow groundwater [11]. Both deep and shallow groundwaters showed insignificant difference in $\mathrm{pH}$ values, the averages of which were in the range of 7.6-7.9. Average electrical conductivity (EC) and total dissolved solids (TDS) of shallow groundwater were approximately $20-25 \%$ higher than those from deep groundwater. Higher TDS in shallow wells could contribute to the influence of anthropogenic activities, such as agriculture and infiltration of sewage water from households. For deeper groundwaters, EC and TDS values were not high suggesting that there may be no contamination from anthropogenic activities. The values of EC and TDS also suggested that deep groundwater may have not been affected from seasonal variation. Therefore, chemical characteristics of deep groundwater could primarily be related to rock-groundwater interaction.

Table 1. Shallow and deep groundwater chemical constituents and their physicochemical properties.

\begin{tabular}{|c|c|c|c|c|c|c|c|c|c|c|c|c|}
\hline \multirow{2}{*}{ Parameters } & \multicolumn{4}{|c|}{$\begin{array}{c}\text { Shallow Groundwater } \\
\text { (Dry Season) }\end{array}$} & \multicolumn{4}{|c|}{$\begin{array}{c}\text { Deep Groundwater } \\
\text { (Dry Season) }\end{array}$} & \multicolumn{4}{|c|}{$\begin{array}{l}\text { Deep Groundwater } \\
\text { (Wet Season) }\end{array}$} \\
\hline & Min & Max & Average & S.D. & Min & Max & Average & S.D. & Min & Max & Average & S.D. \\
\hline Eh $(\mathrm{mV})$ & -90.0 & 199.0 & 73.3 & 85.8 & -131.0 & 171.0 & -13.3 & 85.4 & -132.0 & 168.0 & -3.6 & 84.4 \\
\hline $\mathrm{T}\left({ }^{\circ} \mathrm{C}\right)$ & 25.9 & 29.0 & 27.2 & 1.0 & 24.3 & 37.0 & 29.0 & 2.2 & 26.9 & 34.9 & 30.2 & 1.7 \\
\hline $\mathrm{pH}$ & 7.0 & 8.4 & 7.9 & 0.3 & 6.2 & 8.7 & 7.9 & 0.5 & 6.7 & 8.4 & 7.6 & 0.4 \\
\hline $\mathrm{EC}(\mu \mathrm{S} / \mathrm{cm})$ & 40.0 & 2700 & 569.3 & 576.4 & 42.0 & 1470 & 406.7 & 287.5 & 42.0 & 1500 & 407.9 & 295.5 \\
\hline $\mathrm{Ca}(\mathrm{mg} / \mathrm{L})$ & 6.1 & 170.0 & 42.1 & 42.9 & 2.4 & 64.0 & 17.9 & 15.1 & 2.2 & 94.0 & 16.7 & 20.5 \\
\hline $\mathrm{Mg}(\mathrm{mg} / \mathrm{L})$ & 0.0 & 55.0 & 9.1 & 12.0 & 0.1 & 30.0 & 5.6 & 7.1 & 0.3 & 20.0 & 6.6 & 4.3 \\
\hline $\mathrm{Na}(\mathrm{mg} / \mathrm{L})$ & $<4.0$ & 450.0 & 66.7 & 98.6 & $<4.0$ & 390.0 & 71.0 & 79.1 & $<4.0$ & 380.0 & 66.3 & 78.2 \\
\hline $\mathrm{K}(\mathrm{mg} / \mathrm{L})$ & 2.3 & 64.0 & 22.0 & 19.2 & 0.7 & 47.0 & 7.3 & 7.5 & 1.1 & 22.0 & 6.3 & 4.8 \\
\hline $\mathrm{Fe}(\mathrm{mg} / \mathrm{L})$ & 0.0 & 4.6 & 0.6 & 1.2 & 0.0 & 62.0 & 6.3 & 11.8 & 0.0 & 68.0 & 6.7 & 12.9 \\
\hline $\mathrm{Mn}(\mathrm{mg} / \mathrm{L})$ & 0.0 & 1.9 & 0.3 & 0.5 & 0.0 & 1.7 & 0.3 & 0.4 & 0.0 & 1.2 & 0.3 & 0.3 \\
\hline $\mathrm{SO}_{4}(\mathrm{mg} / \mathrm{L})$ & 2.0 & 510.0 & 49.7 & 114.2 & 0.0 & 51.0 & 7.3 & 10.1 & $<1$ & 52.0 & 7.5 & 12.4 \\
\hline $\mathrm{Cl}(\mathrm{mg} / \mathrm{L})$ & 5.2 & 280.0 & 52.2 & 74.5 & $<1.5$ & 59.0 & 10.1 & 11.9 & $<1.5$ & 56.0 & 6.7 & 10.9 \\
\hline $\mathrm{CO}_{3}(\mathrm{mg} / \mathrm{L})$ & 0.0 & 18.0 & 1.6 & 4.8 & 0.0 & 65.0 & 7.9 & 16.6 & 0.0 & 64.0 & 1.6 & 9.2 \\
\hline $\mathrm{HCO}_{3}(\mathrm{mg} / \mathrm{L})$ & 23.0 & 642.0 & 214.5 & 158.3 & 16.0 & 868.0 & 225.8 & 168.1 & 16.0 & 970.0 & 233.2 & 188.8 \\
\hline $\mathrm{F}(\mathrm{mg} / \mathrm{L})$ & $<0.4$ & 0.8 & 0.4 & 0.1 & $<0.4$ & 9.5 & 1.2 & 2.2 & $<0.4$ & 4.6 & 0.8 & 1.0 \\
\hline $\mathrm{NO}_{3}(\mathrm{mg} / \mathrm{L})$ & $<0.9$ & 34.0 & 7.6 & 8.6 & $<0.9$ & 18.0 & 3.8 & 4.5 & $<0.9$ & 16.0 & 3.4 & 3.6 \\
\hline $\mathrm{TH}$ as $\mathrm{CaCO}_{3}(\mathrm{mg} / \mathrm{L})$ & 16.0 & 600.0 & 142.9 & 144.4 & 8.0 & 270.0 & 67.1 & 63.7 & 12.0 & 270.0 & 68.6 & 63.9 \\
\hline TDS (mg/L) & 26.0 & 1760.0 & 370.2 & 375.5 & 27.0 & 956.0 & 264.6 & 186.8 & 27.0 & 975.0 & 265.1 & 192.0 \\
\hline As $(\mu \mathrm{g} / \mathrm{L})$ & $<2.8$ & 35.0 & 10.7 & 10.5 & $<2.8$ & 416.0 & 42.6 & 80.8 & $<2.8$ & 480.0 & 51.0 & 9.6 \\
\hline
\end{tabular}

$\mathrm{TH}=$ Total Hardness; EC = Electrical Conductivity.

Major ion concentrations $\left(\mathrm{Ca}, \mathrm{Mg}, \mathrm{Na}, \mathrm{K}, \mathrm{CO}_{3}, \mathrm{HCO}_{3}, \mathrm{SO}_{4}\right.$, and $\mathrm{Cl}$ ) in shallow and deep groundwaters were analyzed further for their hydrochemical facies using Piper trilinear and Stiff diagrams (see Figures 6 and 7). The hydrochemical facies of deep groundwater samples both wet and dry seasons were exactly identical; therefore, only wet season data are shown here. Shallow groundwater had higher TDS, which could be attributed to the infiltration of agriculture chemicals and household sewage discharge, thus showing larger Stiff polygons on the map compared to deep groundwater. Both shallow and deep groundwaters, however, showed only four types of facies including $\mathrm{Na}-\mathrm{HCO}_{3}$, $\mathrm{Ca}-\mathrm{Na}-\mathrm{HCO}_{3}, \mathrm{Ca}-\mathrm{HCO}_{3}, \mathrm{Ca}-\mathrm{Na}-\mathrm{HCO}_{3}-\mathrm{Cl}$ types. More than half of deep groundwater samples showed hydrochemical facies of $\mathrm{Na}-\mathrm{HCO}_{3}$ type, which are located, primarily, in the southern part of the basin. This implies that deep groundwater was actually stagnant pore water, since the old-age groundwater usually tends to show a low content of calcium and magnesium [38]. Obviously, deep groundwater was less affected by season, possibly because of slow infiltration rate [39]. 

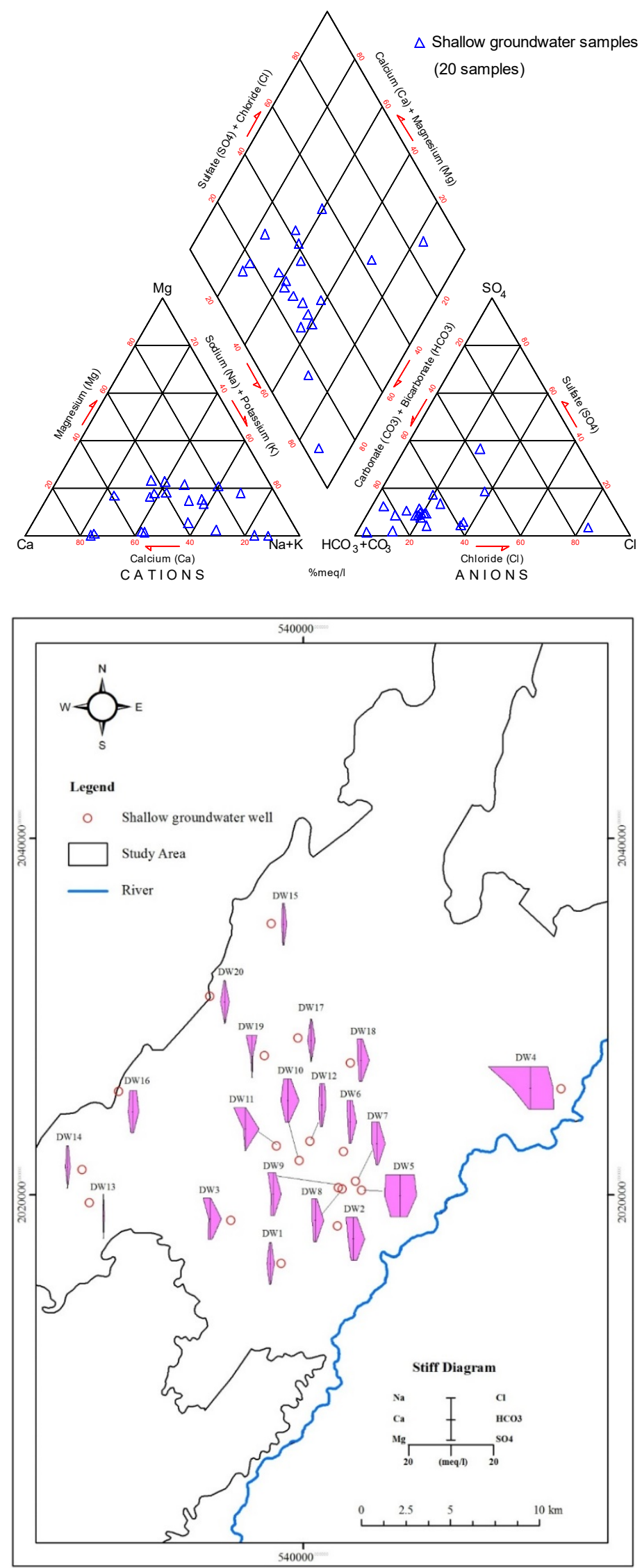

Figure 6. Piper and stiff diagrams for shallow groundwater samples. 

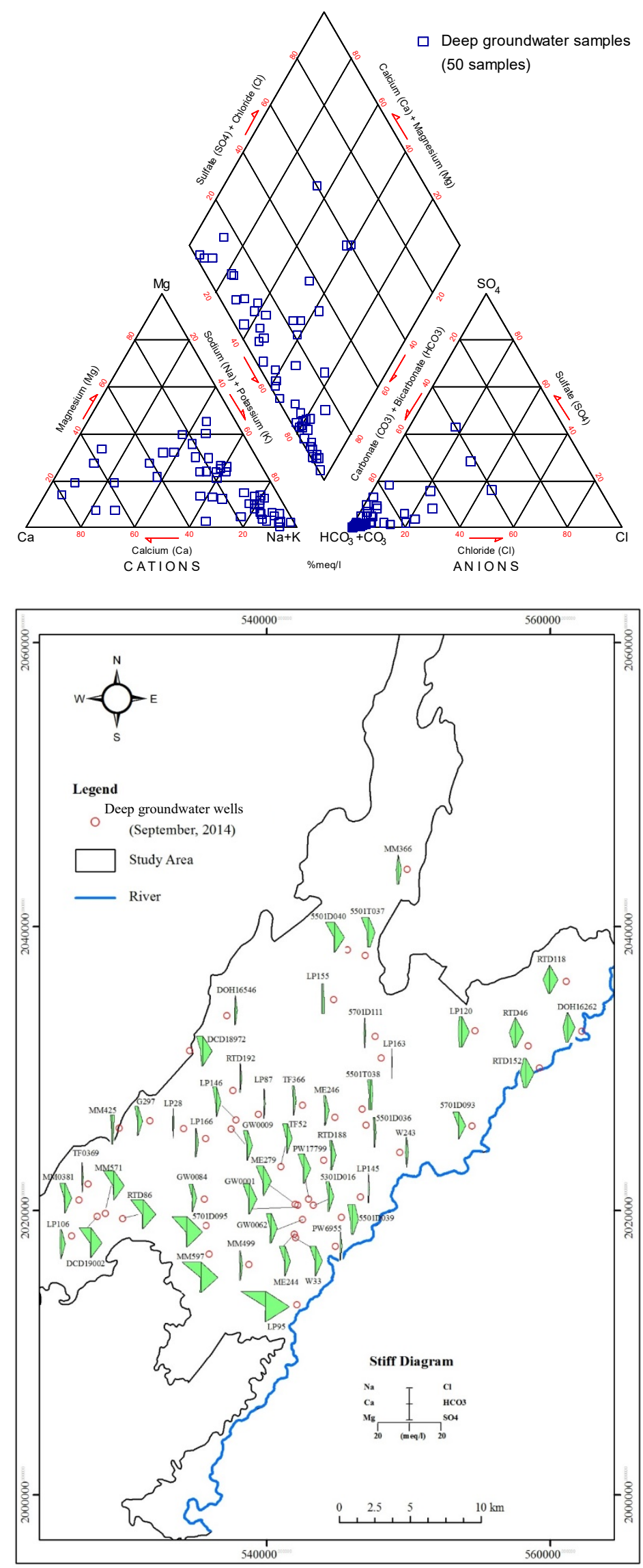

Figure 7. Piper and stiff diagrams for deep groundwater samples (wet season). 


\subsection{Arsenic in Groundwater}

The arsenic concentration was monitored in both shallow ( $\leq 10 \mathrm{~m}$ depth) and deep groundwaters (30-150 m depth). For deep wells, groundwater samplings and analyses were performed in both wet and dry seasons. The distribution of arsenic in 20 shallow dug wells and 50 deep groundwater wells (collected in dry season) are shown in Figure 8. Arsenic contents of shallow dug wells ranged from $<2.8$ to $35 \mu \mathrm{g} / \mathrm{L}$, with an average value of $10.7 \mu \mathrm{g} / \mathrm{L}$. Approximately $40 \%$ of shallow groundwater samples exceeded the WHO's standard for drinking water quality $(10 \mu \mathrm{g} / \mathrm{L})$. Deep groundwater samples collected in the dry season contained a higher arsenic concentration (compared to shallow groundwater), ranging from $<2.8$ to $416 \mu \mathrm{g} / \mathrm{L}$, with an average of $44 \mu \mathrm{g} / \mathrm{L}$. Twelve samples contained arsenic concentration higher than $50 \mu \mathrm{g} / \mathrm{L}$ (Maximum Contaminant Level, MCL). Overall, $36 \%$ of deep groundwaters had arsenic content higher than $10 \mu \mathrm{g} / \mathrm{L}$. Higher arsenic content in deep groundwater $(>50 \mu \mathrm{g} / \mathrm{L}$ ) could be derived from either the dissolution of arsenicbearing minerals, which were being outcropped in the western part of the basin, or the desorption of arsenic from $\mathrm{Fe}(\mathrm{III})$-oxyhydroxides. High arsenic groundwaters were found in the central part of the basin for both shallow and deep aquifers.

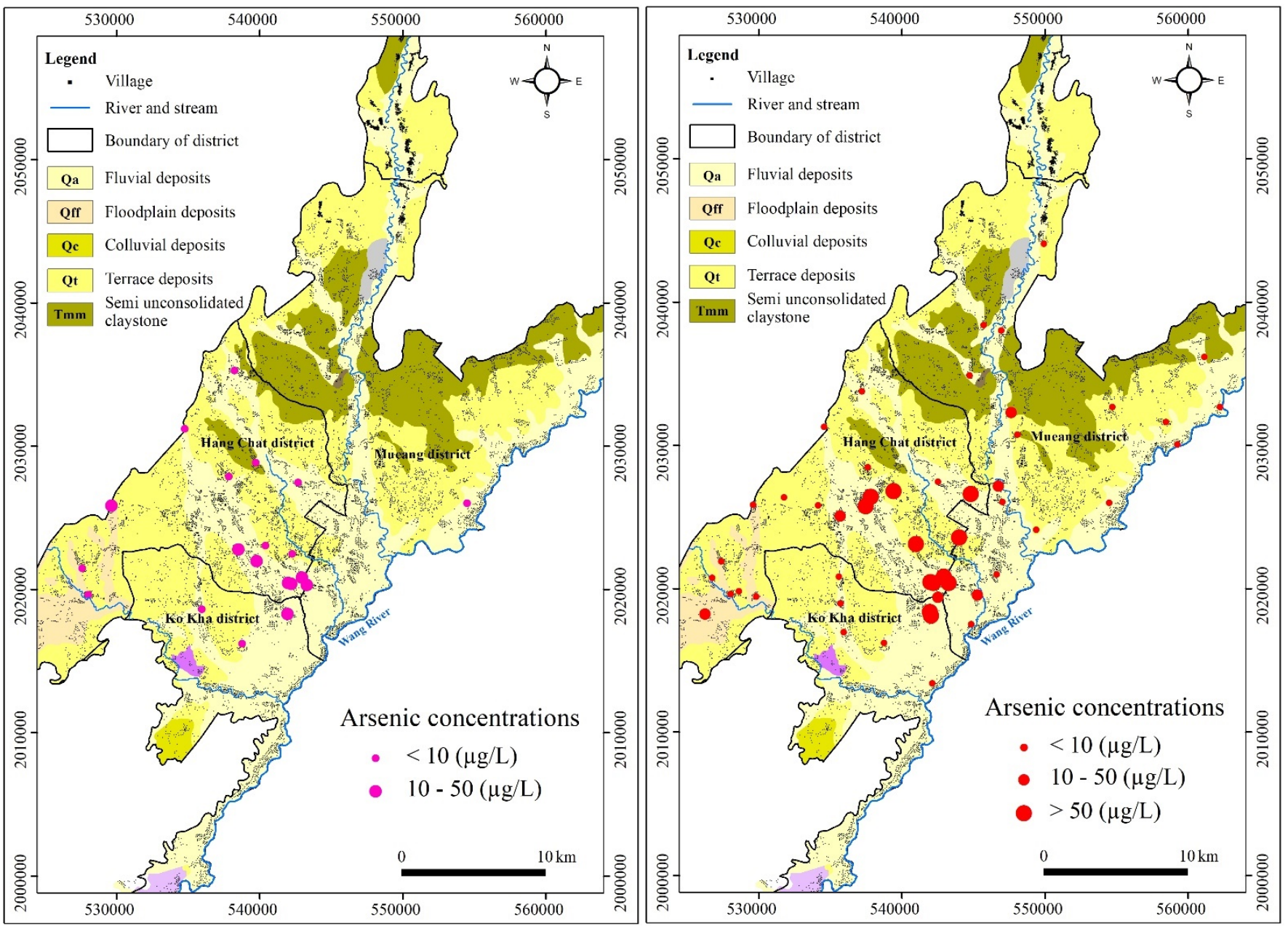

Figure 8. Arsenic content in shallow (left) and deep wells (right) in dry season.

The distribution of arsenic in deep aquifer in wet and dry season are shown in Figure $9 \mathrm{a}, \mathrm{b}$, respectively. The arsenic concentrations in the wet season ranged from $<2.8$ to $480 \mu \mathrm{g} / \mathrm{L}$, with an average value of $51 \mu \mathrm{g} / \mathrm{L}$ whereas, in the dry season, arsenic contents were not significantly different from the wet season, with the range of $<2.8$ to $416 \mu \mathrm{g} / \mathrm{L}$, and the average value of $44 \mu \mathrm{g} / \mathrm{L}$. The arsenic 'hotspots' were located mostly in the highly populated central part of the Lampang Basin. Approximately 35\% of deep groundwater 
samples, in both the wet and dry season, exceeded the WHO's standard for drinking water quality $(10 \mu \mathrm{g} / \mathrm{L})$ and $24 \%$ of deep groundwater samples have arsenic concentrations greater than the MCL of $50 \mu \mathrm{g} / \mathrm{L}$. These results indicated that the quality of the shallow and deep groundwater meant they were not appropriate for consumption and may cause serious health risks from excessive concentration of arsenic.

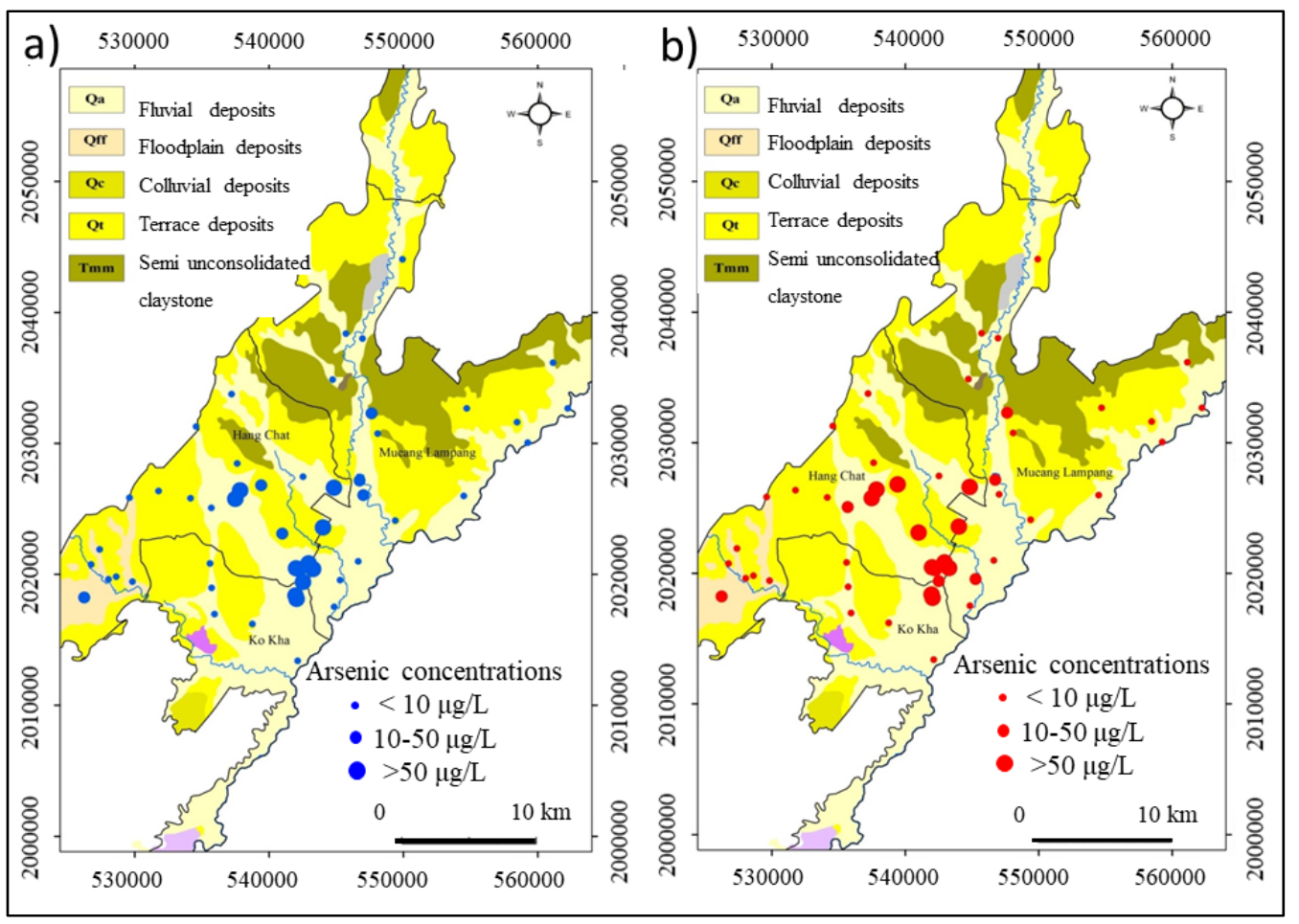

Figure 9. Arsenic content in deep wells for (a) wet season, and (b) dry season.

\subsection{Arsenic Content in Rock Samples}

Four types of rock samples were collected at the locations shown in Figure 4 which included granite (Trgr), sandstone, phyllite, and slate (SD). The samples were analyzed for total arsenic content in $\mathrm{mg} / \mathrm{kg}$. It was found that sandstone, slate, phyllite, and granite had arsenic content of 10.27, 46.49, 1.56, and $32.96 \mathrm{mg} / \mathrm{kg}$, respectively (see Table 2). These arsenic-bearing rock units, located in the recharge area, could be the primary (original) source of arsenic in groundwater in the Lampang Basin. High arsenic content in groundwater found at downstream locations may imply that groundwater, while flowing from the western/northwestern rim areas toward the central and southeastern parts of the study area, picked up arsenic from aquifer or rock materials via dissolution of arsenic-bearing rock/minerals. See the detailed discussion in Section 3.6.

Table 2. Arsenic content in rock samples.

\begin{tabular}{cccc}
\hline No. & Sample Name & Rock Types & Arsenic Content (mg/kg) \\
\hline 1 & WLP1 & Sandstone (SD) & 10.27 \\
2 & WLP2 & Slate (SD) & 46.49 \\
3 & WLP3 & Phyllite (SD) & 1.56 \\
4 & WLP4 & Granite (Trgr) & 32.96 \\
\hline
\end{tabular}

\subsection{Leachable Arsenic from Sediments}

The unconsolidated aquifer samples (Qa and $\mathrm{Qt}$ ) were collected from four groundwater wells during drilling (Samples: 5701D111, 5901J049, 5901J050, and 5701D112) (see Figure 4). The well data, depth of sediment collection, sediment description, and leachable arsenic content were described in Table 3. The sediments consisted of a wide range of materials, 
from clay to sand and gravel. The leachable arsenic content ranged from 0.4 to $3.6 \mathrm{mg} / \mathrm{kg}$. Interestingly, the presence of clays or clay-size sediments were not related to the leachable arsenic level. For example, groundwater well No. 5901J050, which did not contain clay, had leachable arsenic quantities at both shallow $(0.7 \mathrm{mg} / \mathrm{kg})$ and deep $(1.4 \mathrm{mg} / \mathrm{kg})$ depths of sediment sampling, while comparable sediments from other wells, either with or without clays, showed varying arsenic content (0.4 to $3.6 \mathrm{mg} / \mathrm{kg}$ ).

Table 3. Leachable arsenic from sediments.

\begin{tabular}{|c|c|c|c|c|}
\hline No. & Well No. & Depth (m, bgs) & Sediment tYpes & Arsenic (mg/kg) \\
\hline 1 & 5901J049 & $5-10$ & Qa: Clayey sand & 2.3 \\
\hline 2 & 5901J049 & $70-78$ & Qt: Clayey gravel & 2.2 \\
\hline 3 & 5901J050 & $6-10$ & Qa: Gravel & 0.7 \\
\hline 4 & 5901J050 & $132-140$ & Qt: Sand, gravel & 1.4 \\
\hline 5 & 5701D111 & $4-6$ & Qa: Sand, gravel & 3.4 \\
\hline 6 & 5701D111 & $101-114$ & Qt: Clay, sand, gravel & 0.4 \\
\hline 7 & 5701D112 & $3-6$ & Qa: Clay, sand & 3.6 \\
\hline 8 & 5701D112 & $66-72$ & Qt: Clay, sand, gravel & 1.7 \\
\hline
\end{tabular}

Arsenic content in groundwater may not be directly related to the leachable arsenic content from sediments. For example, the groundwater well No. 5901J049, located in the north, has relatively high leachable arsenic content (i.e., sorbed arsenic) in both shallow and deep sediments $(2.2-2.3 \mathrm{mg} / \mathrm{kg})$, but the associated groundwaters in northern zones did not always have a high concentration of arsenic in the groundwater. Rather, shallow wells nearby to 5901J049 had 3-10 times higher arsenic in their groundwater than deep wells. Furthermore, the groundwater well No. 5901J050, located at the south of the study area, showed a low arsenic content of $0.7 \mathrm{mg} / \mathrm{kg}$ in shallow sediment compared to the sample from the deep sediment which was $1.4 \mathrm{mg} / \mathrm{kg}$. However, both shallow and deep groundwaters contained higher arsenic contents than other areas.

It is unlikely that the arsenic content of groundwater is only caused by the dissolution of arsenic-bearing minerals/rocks or the leaching of sediment. It may be affected by other factors, such as adsorption on Fe(III)-oxyhydroxides and clays [17]. Smedley and Kinniburgh [11] suggested that the leached arsenic normally formed as oxy-anions of either $\mathrm{As}(\mathrm{III})$ or $\mathrm{As}(\mathrm{V})$ that could co-exist in groundwater for a very long period of time without re-deposition as minerals. However, these arsenic oxy-anions can be readily adsorbed by means of surface complexation if the aquifers contain Fe(III)-oxyhydroxide phases, such as $\mathrm{Fe}(\mathrm{OH})_{3}(\mathrm{~s})$ and $\mathrm{FeOOH}(\mathrm{s})$, which are unquestionably ubiquitous in aquifers [40]. Therefore, the amount of free arsenic detected in groundwater represents only a minor fraction of the total arsenic in the entire groundwater system, suggesting that there is an enormous amount of arsenic that is available and readily desorbed, causing continuous contamination of groundwater with arsenic [11].

\subsection{Arsenic Speciation Calculation Using PHREEQC}

There are two main types of arsenic species in groundwater, $\mathrm{As}(\mathrm{III})$ and $\mathrm{As}(\mathrm{V})$, where $\mathrm{As}(\mathrm{III})$ is more toxic than $\mathrm{As}(\mathrm{V})$ [41]. As(III) and $\mathrm{As}(\mathrm{V})$ can undergo acid-base equilibria, thus different species are present depending on the $\mathrm{pH}$ of the groundwater. The concentration of arsenic species can be computed by using the PHREEQC program [27] to determine the relative toxicity of the groundwater. PHREEQC calculates aqueous and mineral-water equilibria based on geochemical and thermodynamic conditions requiring physicochemical parameters from field and laboratory analysis data, including temperature, $\mathrm{pH}$, and redox potential (ORP or Eh), as well as chemical concentration of ions. The speciation calculation of arsenic in the shallow aquifer showed that most of the dominant species were in the oxidized form of $\mathrm{As}(\mathrm{V})$ which were less toxic than $\mathrm{As}(\mathrm{III})$. Based on the PHREEQC calculation, arsenic species in deep groundwater could exist in both $\mathrm{As}(\mathrm{V})$ and $\mathrm{As}(\mathrm{III})$ forms. Figure 10 shows dominant arsenic species for the wet and dry seasons, which turned out to be insignificantly different. The spatial distribution of the fraction of $\mathrm{As}(\mathrm{V})$ or $\mathrm{As}(\mathrm{III})$ to 
total arsenic was apparently random, with no particular predictable pattern. Nevertheless, it was clear that deep groundwater contained more arsenic and some deep wells should be reported as hazardous and should be avoided.

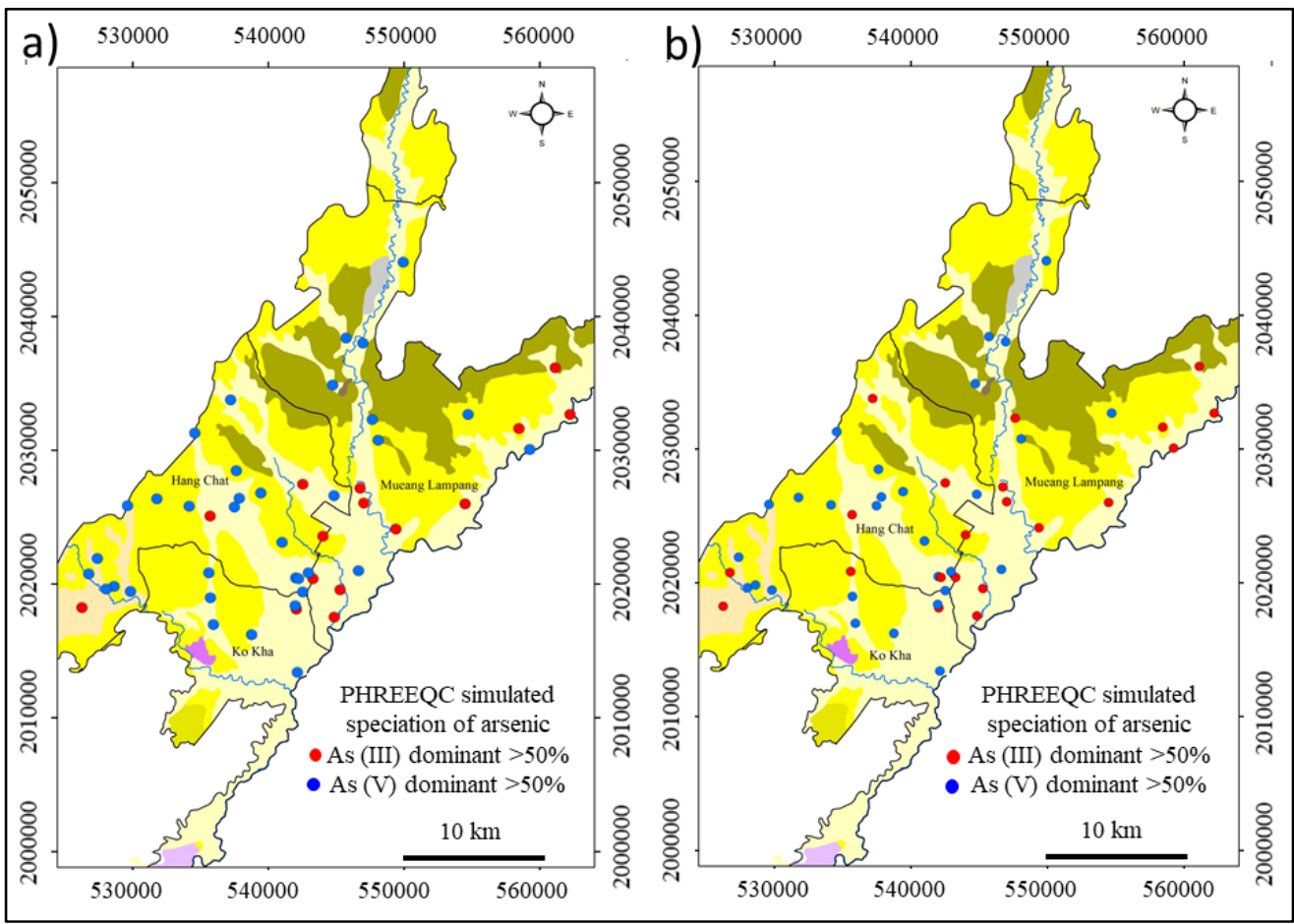

Figure 10. Distribution of $\mathrm{As}(\mathrm{III})$ and $\mathrm{As}(\mathrm{V})$ in deep groundwater in the (a) wet and (b) dry seasons.

\subsection{Implication on Arsenic Transport in Groundwater}

The saturation indices (SI) of minerals with respect to (deep) groundwater samples were calculated using PHREEQC. Modeling results suggested that deep groundwater was supersaturated (SI > 0) with ferrihydrite, lepidocrocite, aragonite, calcite, dolomite, siderite, goethite, maghemite, magnetite, magnesite, hematite, and rhodochrosite. All groundwater samples were undersaturated (SI <0) with arsenic minerals, including arsenolite, clauderite, orpiment, and realgar. These results led to two implications. First, the supersaturation of groundwater with respect to iron (hydr)oxides or iron oxyhydroxides implied the presence of $\mathrm{Fe}(\mathrm{OH})_{3}(\mathrm{~s}), \mathrm{FeOOH}(\mathrm{s})$, or $\mathrm{Fe}_{2} \mathrm{O}_{3}(\mathrm{~s})$ minerals. These solid phases can readily adsorb arsenic oxy-anions of $\mathrm{As}(\mathrm{III})$ and $\mathrm{As}(\mathrm{V})$ by surface complexation processes which are strongly $\mathrm{pH}$ dependent $[35,42]$. Second, the solid phase(s) of arsenic-containing minerals, if originally present, could have been completely dissolved in the flowing groundwater, thus generating arsenic-contaminated groundwaters.

The significant mechanisms for the accumulation of arsenic in sediment material during sediment interactions are adsorption onto and co-precipitation of Fe(III)-oxyhydroxides. $\mathrm{Fe}(\mathrm{III})$-oxyhydroxides in natural water typically have positively charged surfaces in the natural $\mathrm{pH}$ range (approximately 7.2-8.5), thus enabling attraction to the negatively charged oxy-anions of As(III) and As(V) [35]. Results from experimental and geochemical modeling studies by Fuoco et al. [43] showed that both arsenic release processes and co-precipitation of Fe(III)-oxyhydroxides or hydrous ferric oxides (HFOs) could take place simultaneously, and that the adsorption (i.e., surface complexation) of As(III) and As(V) anions significantly controlled the concentration and fate of arsenic in groundwater under a wide range of hydrogeochemical conditions. Since $\mathrm{As}(\mathrm{V})$ are more readily or immediately adsorbed than As(III), negatively charged As(V) ions can become immobilized by adsorption onto Feoxyhydroxides in a pH of less than 9.5 [35]. The geochemical model simulation in this work also revealed that groundwater was supersaturated with respect to Fe(III)-oxyhydroxides, such as ferrihydrite and goethite, which could strongly adsorb arsenic oxy-anions. Thus, 
Fe(III)-oxyhydroxides would potentially adsorb arsenic if the aqueous solution contained a high concentration of arsenic. With a recharge of new water, arsenic in the aquifer could be released into the flowing groundwater by desorption under high $\mathrm{pH}$ condition. Surface complexation study of As adsorption on Fe(III)-oxyhydroxides [35] showed that, for example, at normal groundwater $\mathrm{pH}$ of 8 , only $20 \%$ of $\mathrm{As}(\mathrm{III})$ is detected in groundwater, whereas another $80 \%$ of $\mathrm{As}(\mathrm{III})$ and most of $\mathrm{As}(\mathrm{V})$ are still adsorbed on Fe(III)-oxyhydroxide particles and can act as a large source of As in aquifers under alkaline condition.

\subsection{Human Health Risk Assessment}

Human health risk based on carcinogenic risk was assessed based on the method developed by the U.S. EPA [28] by using total concentration of arsenic in both shallow and deep groundwaters. Table 4 showed the results of assessed health risk and it was found that consumption of arsenic-contaminated groundwater could pose an average carcinogenic risk of $5.84 \times 10^{-4}$ (shallow) and $2.78 \times 10^{-3}$ (deep) for adults, and $1.61 \times 10^{-3}$ (shallow) and $7.65 \times 10^{-3}$ (deep) for children. Although shallow groundwater may cause a lower risk than deep groundwater, these average risks were higher than the acceptable risk suggested by the U.S. EPA. In addition, the average risk for a child was higher than that for an adult. The average hazard quotients (HQ) for shallow and deep groundwaters were greater than unity $(\mathrm{HQ}>1)$ for both adult and child indicating that consumption of these arsenic-contaminated groundwaters could pose an adverse health risk to local people in the western part of the Lampang Basin [28].

Table 4. Human risk assessment for consumption of arsenic-contaminated groundwater in the western part of the Lampang Basin.

\begin{tabular}{|c|c|c|c|c|c|c|c|}
\hline \multirow{2}{*}{\multicolumn{2}{|c|}{$\begin{array}{l}\text { Arsenic Concentration * } \\
(\mu \mathrm{g} / \mathrm{L})\end{array}$}} & \multicolumn{2}{|c|}{$\begin{array}{c}\text { Average Daily Dose (ADD) } \\
(\mathrm{mg} / \mathrm{kg}-\mathrm{d})\end{array}$} & \multicolumn{2}{|c|}{$\begin{array}{c}\text { Carcinogenic Risk (R) } \\
(-)\end{array}$} & \multicolumn{2}{|c|}{$\begin{array}{c}\text { Hazard Quotient }(H Q) \\
(-)\end{array}$} \\
\hline & & Adult & Child & Adult & Child & Adult & Child \\
\hline \multicolumn{8}{|c|}{ Shallow groundwater } \\
\hline Min & $<2.8$ & $<1.02 \times 10^{-4}$ & $<2.80 \times 10^{-4}$ & $<1.53 \times 10^{-4}$ & $<4.20 \times 10^{-4}$ & $<0.34$ & $<0.93$ \\
\hline Max & 35 & $1.27 \times 10^{-3}$ & $3.50 \times 10^{-3}$ & $1.91 \times 10^{-3}$ & $5.25 \times 10^{-3}$ & 4.24 & 22.7 \\
\hline Avg. & 10.7 & $3.89 \times 10^{-4}$ & $1.07 \times 10^{-3}$ & $5.84 \times 10^{-4}$ & $1.61 \times 10^{-3}$ & 1.30 & 3.57 \\
\hline Std. Dev. & 10.5 & $3.82 \times 10^{-4}$ & $1.05 \times 10^{-3}$ & $5.73 \times 10^{-4}$ & $1.58 \times 10^{-3}$ & 1.27 & 3.50 \\
\hline \multicolumn{8}{|c|}{ Deep Groundwater (wet season) } \\
\hline Min & $<2.8$ & $<1.02 \times 10^{-4}$ & $<2.80 \times 10^{-4}$ & $<1.53 \times 10^{-4}$ & $<4.20 \times 10^{-4}$ & $<0.34$ & $<0.93$ \\
\hline Max & 480 & $1.75 \times 10^{-2}$ & $4.80 \times 10^{-2}$ & $2.62 \times 10^{-2}$ & $7.20 \times 10^{-4}$ & 58.2 & 160 \\
\hline Avg. & 51.0 & $1.85 \times 10^{-3}$ & $5.10 \times 10^{-3}$ & $2.78 \times 10^{-3}$ & $7.65 \times 10^{-3}$ & 6.18 & 17.0 \\
\hline Std. Dev. & 9.6 & $3.49 \times 10^{-4}$ & $9.60 \times 10^{-4}$ & $5.24 \times 10^{-4}$ & $1.44 \times 10^{-3}$ & 1.16 & 3.20 \\
\hline
\end{tabular}

*: The above calculation was based on total arsenic content in groundwater.

\section{Conclusions}

In this study, shallow and deep groundwaters in the western part of the Lampang Basin, Northern Thailand, were collected and analyzed for their chemical constituents, as well as arsenic content. Most shallow groundwater samples showed $\mathrm{Ca}-\mathrm{Na}-\mathrm{HCO}_{3}$ and $\mathrm{Ca}-\mathrm{HCO}_{3}$ water types, whereas deep groundwater samples were of $\mathrm{Na}-\mathrm{HCO}_{3}$ and $\mathrm{Ca}-\mathrm{Na}-\mathrm{HCO}_{3}$ types. High arsenic concentrations were found in the central part of the study area. Arsenic in shallow groundwater was in the range of $<2.8$ to $35 \mu \mathrm{g} / \mathrm{L}$ with a mean of $10.7 \mu \mathrm{g} / \mathrm{L}$, whereas arsenic in deep groundwater ranged from $<2.8$ to $480 \mu \mathrm{g} / \mathrm{L}$ with a mean of $51.0 \mu \mathrm{g} / \mathrm{L}$. A geochemical modeling study using the PHREEQC program revealed that deep groundwater contained toxic As(III), as the dominant species, more than shallow groundwater. Arsenic in groundwater of the Lampang Basin may have been derived from the leaching of rocks, which could also have been the primary source of the subsurface arsenic in the study area. A secondary source of arsenic, which is more significant, could be derived from the leaching of sorbed arsenic in aquifer from co-precipitated Fe(III)-oxyhydroxides in sediments. Quantitative health risk assessment from consuming arsenic-contaminated groundwater showed that the average carcinogenic risk values were as high as $2.78 \times 10^{-3}$ and $7.65 \times 10^{-3}$ for adult and child, respectively, 
which were significantly higher than the acceptable level $\left(1 \times 10^{-4}\right)$. The adverse health impact should be notified or warned when consuming arsenic-contaminated groundwater without pre-treatment. Long-term and continuous monitoring of arsenic in groundwater should be implemented in any high-risk areas and appropriate groundwater treatment program (i.e., arsenic removal) should be applied in order to reduce potential health risk from arsenic consumption.

Author Contributions: Conceptualization, S.S. (Schradh Saenton); Data curation, S.S. (Saowani Sangkajan) and N.S.; Formal analysis, S.S. (Saowani Sangkajan) and N.S.; Funding acquisition, S.S. (Schradh Saenton); Investigation, S.S. (Saowani Sangkajan) and N.S.; Resources, S.S. (Saowani Sangkajan); Software, S.S. (Schradh Saenton); Supervision, S.S. (Schradh Saenton); Validation, S.S. (Saowani Sangkajan) and N.S.; Visualization, S.S. (Saowani Sangkajan) and N.S.; Writing-original draft, S.S. (Saowani Sangkajan) and N.S.; Writing-review and editing, S.S. (Schradh Saenton). All authors have read and agreed to the published version of the manuscript.

Funding: This research work was partially supported by Chiang Mai University; Thailand Science Research and Innovation (TSRI) (Grant number RDG6230005).

Institutional Review Board Statement: Not applicable.

Informed Consent Statement: Not applicable.

Data Availability Statement: Groundwater level and groundwater quality data for each monitoring well, as well as PHREEQC simulation input/output files, are available upon request.

Acknowledgments: This research work was partially supported by Chiang Mai University, Thailand; and Thailand Science Research and Innovation (TSRI) (Grant number RDG6230005). The authors would also like to acknowledge the Department of Groundwater Resources, Ministry of Natural Resources and Environment, Thailand for providing groundwater monitoring data for this study.

Conflicts of Interest: The authors declare no conflict of interest. The funders had no role in the design of the study; in the collection, analyses, or interpretation of data; in the writing of the manuscript, or in the decision to publish the results.

\section{References}

1. Ahmed, K.M.; Bhattacharya, P.; Hasan, M.A.; Akhter, S.H.; Alam, S.M.; Bhuyian, M.H.; Imam, M.B.; Khan, A.A.; Sracek, O. Arsenic enrichment in groundwater of the alluvial aquifers in Bangladesh: An overview. Appl. Geochem. 2004, 19, 181-200. [CrossRef]

2. Kim, K.-W.; Chanpiwat, P.; Hanh, H.T.; Phan, K.; Sthiannopkao, S. Arsenic geochemistry of groundwater in Southeast Asia. Front. Med. 2011, 5, 420-433. [CrossRef]

3. Ahuja, S. (Ed.) Arsenic Contamination of Groundwater: Mechanism, Analysis, and Remediation; John Wiley \& Sons, Ltd.: Hoboken, NJ, USA, 2008; 387p.

4. Ravenscroft, P.; Brammer, H.; Richards, K. Arsenic Pollution: A Global Synthesis; John Wiley \& Sons, Ltd.: Hoboken, NJ, USA, 2011; 588p.

5. Ministry of Industry. Notification of the Ministry of Industry on the Groundwater Chemical Constituent Standards and Regulations. R. Gov. Gaz. 1999, 12, 178-189.

6. World Health Organization. Guidelines for Drinking Water Quality, 3rd ed.; World Health Organization: Geneva, Switzerland, 2008; pp. 306-308.

7. Maity, J.P.; Kar, S.; Liu, J.-H.; Jean, J.-S.; Chen, C.-Y.; Bundschuh, J.; Santra, S.C.; Liu, C.-C. The potential for reductive mobilization of arsenic $[\mathrm{As}(\mathrm{V})$ to $\mathrm{As}(\mathrm{III})]$ by OSBH2 (Pseudomonas stutzeri) and OSBH5 (Bacillus cereus) in an oil-contaminated site. J. Environ. Sci. Health Part A 2011, 46, 1239-1246. [CrossRef] [PubMed]

8. Welch, A.H.; Stollenwerk, K.G. Arsenic in Ground Water: Geochemistry and Occurrence; Kluwer Academic Publishers: Dordrecht, The Netherlands, 2003; 475p.

9. Apollaro, C.; Di Curzio, D.; Fuoco, I.; Buccianti, A.; Dinelli, E.; Vespasiano, G.; Castrignano, A.; Rusi, S.; Barca, D.; Figoli, A.; et al. A multivariate non-parametric approach for estimating probability of exceeding the local natural background level of arsenic in the aquifers of Calabria region (Southern Italy). Sci. Total Environ. 2022, 806, 150345. [CrossRef]

10. Drahota, P.; Filippi, M. Secondary arsenic minerals in the environment: A review. Environ. Int. 2009, 35, 1243-1255. [CrossRef]

11. Smedley, P.L.; Kinniburgh, D.G. A review of the source, behaviour and distribution of arsenic in natural waters. Appl. Geochem. 2002, 17, 517-568. [CrossRef]

12. Shankar, S.; Shanker, U. Shikha, Arsenic contamination of groundwater: A review of sources, prevalence, health risks, and strategies for mitigation. Sci. World J. 2014, 2014, 304524. [CrossRef] 
13. Welch, A.H.; Lico, M.S.; Hughes, J.L. Arsenic in ground water of the western United States. Groundwater 1988, 26, 333-347. [CrossRef]

14. Welch, A.H.; Westjohn, D.; Helsel, D.R.; Wanty, R.B. Arsenic in ground water of the United States: Occurrence and geochemistry. Groundwater 2000, 38, 589-604. [CrossRef]

15. Mok, W.M.; Wai, C.M. Distribution and mobilization of arsenic and antimony species in the Coeur D'Alene River, Idaho. Environ. Sci. Technol. 1990, 24, 102-108. [CrossRef]

16. Anderson, L.C.; Bruland, K.W. Biogeochemistry of arsenic in natural waters: The importance of methylated species. Environ. Sci. Technol. 1991, 25, 420-427. [CrossRef]

17. Bissen, M.; Frimmel, F.H. Arsenic-A review. Part I: Occurrence, toxicity, speciation, mobility. Acta Hydrochim. Hydrobiol. 2003, 31, 9-18. [CrossRef]

18. Klump, S.; Kipfer, R.; Cirpka, O.A.; Harvey, C.F.; Brennwald, M.S.; Ashfaque, K.N.; Badruzzaman, A.B.M.; Hug, S.J.; Imboden, D.M. Groundwater dynamics and arsenic mobilization in Bangladesh assessed using noble gases and tritium. Environ. Sci. Technol. 2006, 40, 243-250. [CrossRef] [PubMed]

19. Tellam, J.H.; Barker, R.D. Towards prediction of saturated-zone pollutant movement in groundwaters in fractured permeablematrix aquifers: The case of the UK Permo-Triassic sandstones. Geol. Soc. Lond. Spec. Publ. 2006, 263, 1-48. [CrossRef]

20. Medici, G.; Smeraglia, L.; Torabi, A.; Botter, C. Review of modeling approaches to groundwater flow in deformed carbonate aquifers. Groundwater 2021, 59, 334-351. [CrossRef]

21. Herath, I.; Vithanage, M.; Bundschuh, J.; Maity, J.P.; Bhattacharya, P. Natural arsenic in global groundwaters: Distribution and geochemical triggers for mobilization. Curr. Pollut. Rep. 2016, 2, 68-89. [CrossRef]

22. Joseph, T.; Dubey, B.; McBean, E.A. Human health risk assessment from arsenic exposures in Bangladesh. Sci. Total Environ. 2015, 527, 552-560. [CrossRef]

23. Bundschuh, J.; Litter, M.I.; Parvez, F.; Román-Ross, G.; Nicolli, H.B.; Jean, J.-S.; Liu, C.-W.; López, D.; Armienta, M.A.; Guilherme, L.R. One century of arsenic exposure in Latin America: A review of history and occurrence from 14 countries. Sci. Total Environ. 2012, 429, 2-35. [CrossRef]

24. Angelone, M.; Cremisini, C.; Piscopo, V.; Proposito, M.; Spaziani, F. Influence of hydrostratigraphy and structural setting on the arsenic occurrence in groundwater of the Cimino-Vico volcanic area (central Italy). Hydrogeol. J. 2009, 17, 901-914. [CrossRef]

25. Department of Groundwater Resources (DGR). The State of Groundwater Annual Report: Thailand Groundwater Monitoring Networks Project; Final Report; Department of Groundwater Resources: Bangkok, Thailand, 2018.

26. Bashkin, V.N.; Wongyai, K. Environmental fluxes of arsenic from lignite mining and power generation in northern Thailand. Environ. Geol. 2002, 41, 883-888.

27. Parkhurst, D.L.; Appelo, C.A.J. Description of Input and Examples for PHREEQC Version 3-A Computer Program for Speciation, Batch-Reaction, One-Dimensional Transport, and Inverse Geochemical Calculations; Book 6 Series Techniques and Methods; U.S Geological Survey: Reston, VA, USA, 2013.

28. U.S. Environmental Protection Agency. Guidelines for Carcinogen Risk Assessment; U.S. Environmental Protection Agency: Washington, DC, USA, 2005.

29. Department of Mineral Resources. Geologic Map of Lampang Province; Thailand's Ministry of Industry: Bangkok, Thailand, 2007.

30. Department of Groundwater Resources. Groundwater Map of Lampang Province; Thailand's Ministry of Natural Resources and Environment: Bangkok, Thailand, 2007.

31. Wenzel, W.W.; Kirchbaumer, N.; Prohaska, T.; Stingeder, G.; Lombi, E.; Adriano, D.C. Arsenic fractionation in soils using an improved sequential extraction procedure. Anal. Chim. Acta 2001, 436, 309-323. [CrossRef]

32. Lim, M.; Han, G.-C.; Ahn, J.-W.; You, K.-S.; Kim, H.-S. Leachability of arsenic and heavy metals from mine tailings of abandoned metal mines. Int. J. Environ. Res. Public Health 2009, 6, 2865-2879. [CrossRef] [PubMed]

33. Li, J.; Kosugi, T.; Riya, S.; Hashimoto, Y.; Hou, H.; Terada, A.; Hosomi, M. Use of batch leaching tests to quantify arsenic release from excavated urban soils with relatively low levels of arsenic. J. Soils Sediments 2017, 17, 2136-2143. [CrossRef]

34. Allison, J.D.; Brown, D.S.; Novo-Gradac, K.J. MINTEQA2/PRODEFA2. A Geochemical Assessment Model for Environmental Systems; Version 3.0 User's Manual; U.S. Environmental Agency (EPA/600/3-91/021); U.S. Environmental Agency: Washington, DC, USA, 1991.

35. Dzombak, D.A.; Morel, F.M. Surface Complexation Modeling: Hydrous Ferric Oxide; John Wiley \& Sons: Hoboken, NJ, USA, $1991 ; 416 \mathrm{p}$

36. Radfard, M.; Yunesian, M.; Nabizadeh, R.; Biglari, H.; Nazmara, S.; Hadi, M.; Yousefi, N.; Yousefi, M.; Abbasnia, A.; Mahvi, A.H. Drinking water quality and arsenic health risk assessment in Sistan and Baluchestan, Southeastern Province. Iran. Hum. Ecol. Risk Assess 2019, 25, 949-965. [CrossRef]

37. Rasool, A.; Farooqi, A.; Masood, S.; Hussain, K. Arsenic in groundwater and its health risk assessment in drinking water of Mailsi, Punjab, Pakistan. Hum. Ecol. Risk Assess 2016, 22, 187-202. [CrossRef]

38. Freeze, R.A.; Cherry, J.A. Groundwater; Prentice-Hall, Inc.: Hoboken, NJ, USA, 1979; 604p.

39. Dhungel, R.; Fiedler, F. Water Balance to Recharge Calculation: Implications for Watershed Management Using Systems Dynamics Approach. Hydrology 2016, 3, 13. [CrossRef]

40. Harvey, C.F.; Swartz, C.H.; Badruzzaman, A.; Keon-Blute, N.; Yu, W.; Ali, M.A.; Jay, J.; Beckie, R.; Niedan, V.; Brabander, D. Arsenic mobility and groundwater extraction in Bangladesh. Science 2002, 298, 1602-1606. [CrossRef] 
41. Silver, S.; Phung, L.T. Genes and enzymes involved in bacterial oxidation and reduction of inorganic arsenic. Appl. Environ. Microbiol. 2005, 71, 599-608. [CrossRef]

42. Drever, J.I. The Geochemistry of Natural Waters: Surface and Groundwater Environments, 3rd ed.; Prentice-Hall, Inc.: Hoboken, NJ, USA, 1997; 436p.

43. Fuoco, I.; De Rosa, R.; Barca, D.; Figoli, A.; Gabriele, B.; Apollaro, C. Arsenic polluted waters: Application of geochemical modelling as a tool to understand the release and fate of the pollutant in crystalline aquifers. J. Environ. Manag. 2022, 301, 113796. [CrossRef] 